\title{
An Improved, Scalable Synthesis of the Selective Serotonin 2A Receptor Agonist 25CN-NBOH
}

\author{
Emil Märcher-Rørsted (D) \\ Jitka Nykodemová \\ Jesper L. Kristensen* (D) \\ Department of Drug Design and Pharmacology, University of Copenhagen, \\ 2100 Copenhagen, Denmark \\ jesper.kristensen@sund.ku.dk
}
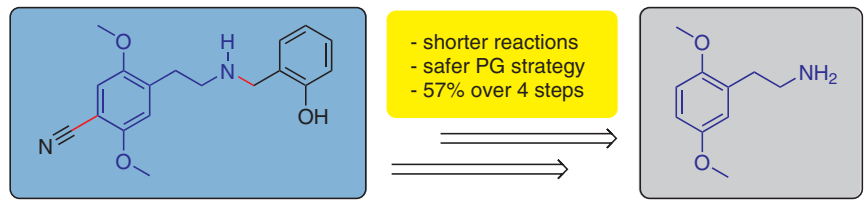

Received: 08.04.2021

Accepted after revision: 26.04 .2021

Published online: 08.06 .2021

DOI: 10.1055/a-1524-4439; Art ID: so-2021-d0020-I

License terms: cc)

(c) 2021. The Author(s). This is an open access article published by Thieme under the terms of the Creative Commons Attribution-NonDerivative-NonCommercial-License, permitting copying and reproduction so long as the original work is given appropriate credit. Contents may not be used for commercial purposes or adapted, remixed, transformed or built upon. (https://creativecommons.org/licenses/by-nc-nd/4.0/)

Abstract 4-\{2-[(2-hydroxybenzyl)amino]ethyl\}-2,5-dimethoxybenzonitrile $(25 \mathrm{CN}-\mathrm{NBOH})$ was first reported as a potent and highly selective serotonin 2A receptor (5-HT2AR) agonist in 2014. The compound has since found extensive use as a pharmacological tool in a variety of in vivo and in vitro studies. In the present study, we present an improved and scalable synthesis of $25 \mathrm{CN}-\mathrm{NBOH}$ making this compound readily available to the scientific community.

Key words amines, benzylation, chemoselectivity, medicinal chemistry, condensation

In recent decades classic psychedelic compounds such as psilocybin and LSD have been revisited as putative therapeutics by the scientific community, which has led to several groundbreaking clinical studies into the therapeutic potential of these molecules. ${ }^{1-3}$

The overall pharmacological profiles of the classical psychedelics differ somewhat but they share a similar pharmacological component: agonist activity at the serotonin (5-hydroxytryptamine) $2 \mathrm{~A}$ receptor $\left(5-\mathrm{HT}_{2 \mathrm{~A}} \mathrm{R}\right)$, which a substantial amount of experimental evidence suggests is a key component both for the psychedelic effects mediated by the compounds and for their efficacy in drug-assisted psychotherapy.

$25 \mathrm{CN}-\mathrm{NBOH}$ (1) was discovered in 2014 and is one of the most selective $5-\mathrm{HT}_{2 \mathrm{~A}} \mathrm{R}$ agonists reported to date (Scheme 1). This compound displays high binding affinity to the 5-HT ${ }_{2 A} \mathrm{R}\left(\mathrm{K}_{\mathrm{i}}=\mathrm{ca}\right.$. $\left.1 \mathrm{nM}\right)$ and robust selectivity for 5$\mathrm{HT}_{2 \mathrm{~A}} \mathrm{R}$ over $5-\mathrm{HT}_{2 \mathrm{~B}} \mathrm{R}$ and $5-\mathrm{HT}_{2 \mathrm{C}} \mathrm{R}$ in various radio-ligand- binding and functional assays and is generally selective for this class of serotonin receptors over other receptor targets. ${ }^{11-13}$

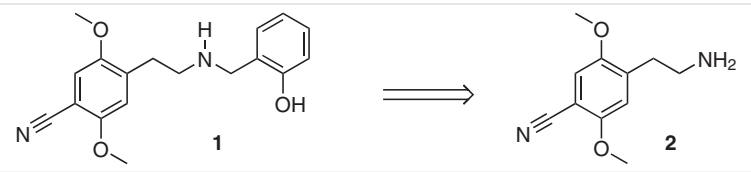

Scheme 1 25CN-NBOH (1) and the parent phenethylamine 2C-CN (2)

While these psychedelic molecules both act as agonists of $5-\mathrm{HT}_{2 \mathrm{~A}} \mathrm{R}$, they are not particularly selective for this receptor. ${ }^{4-10}$

Due to its high selectivity over other serotonin receptors in functional assays, $\mathbf{1}$ has been utilized as a key tool in several in vivo investigations involving animal models of hallucinogenic effects, characteristic of 5HT2AR activation. ${ }^{11,14,15}$

Previously reported synthetic routes to 1 involve several low-yielding and sluggish reactions and use several hazardous reagents as summarized in Scheme $2 .{ }^{16}$<smiles>COc1ccc(OC)c(CCN)c1</smiles><smiles>COc1cc(CCN2C(=O)c3ccccc3C2=O)c(OC)cc1CCN</smiles>

Scheme 2 Previously published synthesis of $2 \mathrm{C}-\mathrm{CN}$ (2). Reagents and conditions: a) $\mathrm{BBr}_{3}, \mathrm{DCM},-78^{\circ} \mathrm{C}$ to rt, $48 \mathrm{~h}$; b) phthalic anhydride, DMF, $153^{\circ} \mathrm{C}$, overnight; c) CuCN, DMF, $153^{\circ} \mathrm{C}, 5 \mathrm{~h}$; d) $\mathrm{N}_{2} \mathrm{H}_{4}, \mathrm{EtOH}, 78^{\circ} \mathrm{C}, 15 \mathrm{~min}$. 
Herein, we present a considerably simplified and improved, fully characterized synthetic route to $\mathbf{1}$ from commercially available 2,5-dimethoxyphenethylamine $(2 \mathrm{C}-\mathrm{H}$, 3) that is characterized by high yields, short reaction times, and a safer functional group protection strategy.

The improved sequence of reactions begins by protection of the primary amine moiety of $\mathbf{3}$ as the trifluoroacetamide 4, as shown in Scheme 3. Previously, the amine was protected as the phthalimide, requiring an overnight reaction and subsequent deprotection with the toxic reagent hydrazine. The trifluoroacetamide protecting group, on the other hand, is easily removed by treatment with sodium borohydride and the protection is complete within 3 hours giving an almost quantitative yield of the desired protected amine. Next, the 4-position was functionalized by formylation using Rieche conditions. Acquisition of the benzaldehyde 5 was immediately followed by direct cyanation, carried out in a single step using hydroxylamine-O-sulfonic acid in aqueous medium. ${ }^{17}$

Formyl analogue 5 was obtained from 4 in 83\% yield and 6 from 5 in 75\% yield. This compares well with the previously reported approach resulting in 33\% yield over three steps. ${ }^{16}$ Worthy of note, although we have previously reported the synthesis of $\mathbf{1}$ using the original literature procedure, we found that isolated yields using the original cyanation procedure (the literature reports up to $91 \%$ isolated yield) are subject to large variability. ${ }^{12,16}$ This initially prompted our search for a more reliable procedure for obtaining 2.

Finally, the cleavage of the trifluoroacetamide protecting group unmasked the fully functionalized parent phenethylamine $\mathbf{2}$, which was converted into $\mathbf{1}$ by reductive amination as previously reported. ${ }^{12}$ This route gives $\mathbf{1}$ in $37 \%$ yield over five steps from 3 .

The direct cyanation of aldehyde $\mathbf{5}$ was efficient up to the gram scale (method A), but at higher scales (2-6 g), these reaction conditions gave considerably lower yields of 6 and an incomplete conversion of the aldoxime intermediate 7 . This encouraged us to investigate a stepwise cyanation route, first isolating 7 by reaction of the benzaldehyde with hydroxylamine hydrochloride and its subsequent dehydration using neat acetic anhydride at reflux (method B). Both reactions were efficient giving the crude phenethylamine with minor impurities removable by crystallization. This two-step route consistently gave quantitative yields of $\mathbf{6}$ on a multigram scale.

The total overall yield is improved to $20 \%$ with only a single overnight reaction and a single chromatographic purification. This synthetic approach is recommended as an alternative strategy for the procurement of larger quantities of the phenethylamine $\mathbf{1}$, albeit that it adds an additional step to the synthetic route.

In summary, we have developed a new, more rapid, more efficient, and more convenient route for the synthesis of the selective $5-\mathrm{HT}_{2 \mathrm{~A}} \mathrm{R}$ agonist $\mathbf{1}^{18}$ This route presents a scalable alternative to the previously published literature procedure, with a safer protection group strategy (Scheme 4). Furthermore, the route affords a higher overall yield than previously reported, utilizes less challenging experimental setups, and requires minimal chromatographic purification steps. This new approach to the synthesis of the compound should make this valuable pharmacological tool readily available to the scientific community.

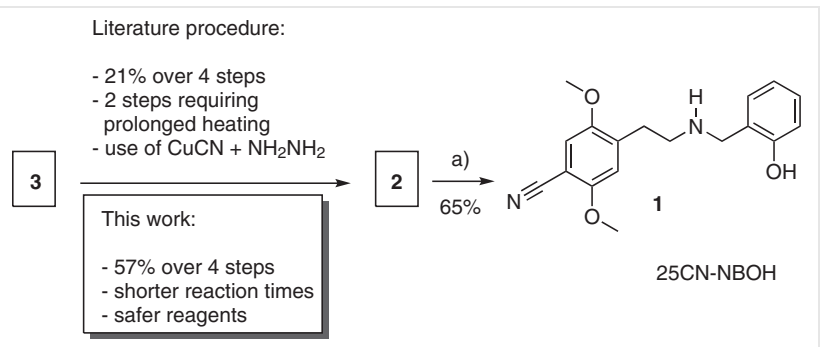

Scheme 4 Comparison with previously reported synthesis of $\mathbf{2}$ and completion of synthesis of $\mathbf{1}$. Reagents and conditions: a) salicylaldehyde, $\mathrm{NaBH}_{4}$ anhydrous EtOH, $0{ }^{\circ} \mathrm{C}$ to rt, $13 \mathrm{~h}$.

\section{Conflict of Interest}

The authors declare no conflict of interest.

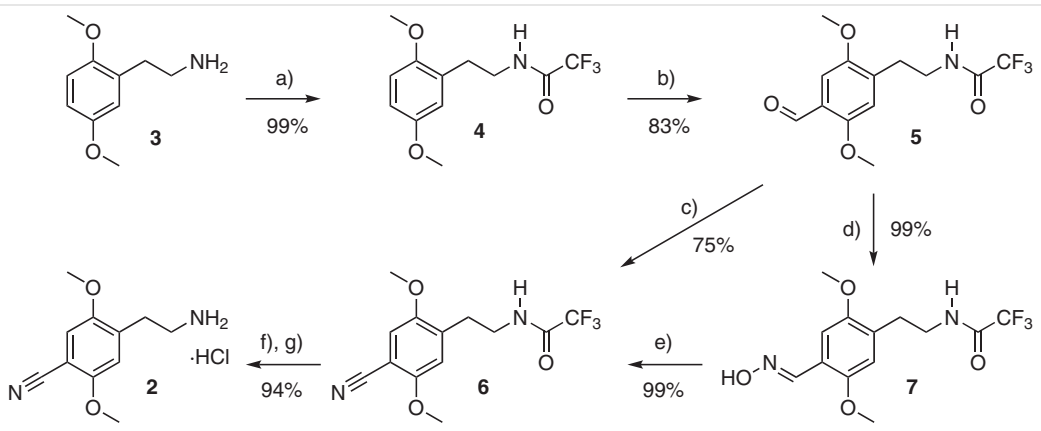

Scheme 3 Improved synthesis of $2 \mathrm{C}$-CN (2). Reagents and conditions: a) TFAA, TEA, anhydrous DCM, $0{ }^{\circ} \mathrm{C}$ to rt, $3 \mathrm{~h}$; b) TiCl , dichloromethyl methyl ether, anhydrous $\mathrm{DCM},-78^{\circ} \mathrm{C}, 30 \mathrm{~min} ; \mathrm{c}$ ) method $\mathrm{A}$ : hydroxylamine-O-sulfonic acid, $\mathrm{H}_{2} \mathrm{O}, \mathrm{AcOH}, 60^{\circ} \mathrm{C}, 48 \mathrm{~h} ; \mathrm{d}$ ) method $\mathrm{B}: \mathrm{NH} \mathrm{H}_{2} \mathrm{OH}, \mathrm{HCl}, \mathrm{EtOH}, 70^{\circ} \mathrm{C}$, 15 min; e) $\mathrm{Ac}_{2} \mathrm{O}$, reflux, 3.5 h; f) $\mathrm{NaBH}_{4}$, EtOH, rt, 1 h, reflux, 2.5 h; g) $4 \mathrm{M} \mathrm{HCl}$, i-PrOH. 


\section{Funding Information}

The Lundbeck foundation (R208-2015-3140) is gratefully acknowledged for financial support.

\section{Supporting Information}

Supporting information for this article is available online at https://doi.org/10.1055/a-1524-4439.

\section{References and Notes}

(1) Griffiths, R. R.; Johnson, M. W.; Carducci, M. A.; Umbricht, A.; Richards, W. A.; Richards, B. D.; Cosimano, M. P.; Klinedinst, M. A. J. Psychopharmacol. 2016, 30, 1181.

(2) Carhart-Harris, R. L.; Bolstridge, M.; Rucker, J.; Day, C. M. J.; Erritzoe, D.; Kaelen, M.; Bloomfield, M.; Rickard, J. A.; Forbes, B.; Feilding, A.; Taylor, D.; Pilling, S.; Curran, V. H.; Nutt, D. J. Lancet Psychiatry 2016, 3, 619.

(3) Carhart-Harris, R. L.; Erritzoe, D.; Williams, T.; Stone, J. M.; Reed, L. J.; Colasanti, A.; Tyacke, R. J.; Leech, R.; Malizia, A. L.; Murphy, K.; Hobden, P.; Evans, J.; Feilding, A.; Wise, R. G.; Nutt, D. J. Proc. Natl. Acad. Sci. U.S.A. 2012, 109, 2138.

(4) Vollenweider, F. X.; Vollenweider-Scherpenhuyzen, M. F. I.; Bäbler, A.; Vogel, H.; Hell, D. Neuroreport 1998, 9, 3897.

(5) Madsen, M. K.; Fisher, P. M.; Burmester, D.; Dyssegaard, A.; Stenbæk, D. S.; Kristiansen, S.; Johansen, S. S.; Lehel, S.; Linnet, K.; Svarer, C.; Erritzoe, D.; Ozenne, B.; Knudsen, G. M. Neuropsychopharmacology 2019, 44, 1328.

(6) López-Giménez, J. F.; González-Maeso, J. Curr. Top. Behav. Neurosci. 2018, 36, 45.

(7) Kometer, M.; Schmidt, A.; Bachmann, R.; Studerus, E.; Seifritz, E.; Vollenweider, F. X. Biol. Psychiatry 2012, 72, 898.

(8) Halberstadt, A. L.; Geyer, M. A. Int. J. Neuropsychopharmacol. 2013, 16, 2165.

(9) González-Maeso, J.; Sealfon, S. C. Trends Neurosci. 2009, 32, 225.

(10) Nichols, D. E. Pharmacol. Rev. 2016, 68, 264.

(11) Halberstadt, A. L.; Sindhunata, I. S.; Scheffers, K.; Flynn, A. D.; Sharp, R. F.; Geyer, M. A.; Young, J. W. Neuropharmacology 2016, 107, 364.

(12) Hansen, M.; Phonekeo, K.; Paine, J. S.; Leth-Petersen, S.; Begtrup, M.; Bräuner-Osborne, H.; Kristensen, J. L. Chem. Neurosci. 2014, 5, 243.

(13) Jensen, A. A.; McCorvy, J. D.; Petersen, S. L.; Bundgaard, C.; Liebscher, G.; Kenakin, T. P.; Brauner-Osborne, H.; Kehler, J.; Kristensen, J. L. J. Pharmacol. Exp. Ther. 2017, 361, 441.
(14) Buchborn, T.; Lyons, T.; Knöpfel, T. Front. Pharmacol. 2018, 9, 17.

(15) Halberstadt, A. L.; Van Der Zee, J. V. F.; Chatha, M.; Geyer, M. A.; Powell, S. B. Psychopharmacology 2019, 236, 821.

(16) Cheng, A. C.; Castagnoli, N. J. Med. Chem. 1984, 27, 513.

(17) Quinn, D. J.; Haun, G. J.; Moura-Letts, G. Tetrahedron Lett. 2016, $57,3844$.

(18) Synthesis of 4-\{2-[(2-Hydroxybenzyl)amino]ethyl\}-2,5-dimethoxybenzonitrile Hydrochloride (1)

A flame-dried round-bottom flask equipped with a stirrer bar and flushed with argon was charged with 2 (300 mg, 1.24 mmol), salicylaldehyde $(0.144 \mathrm{~mL}, 1.36 \mathrm{mmol})$, trimethylamine $(0.172 \mathrm{~mL}, 1.24 \mathrm{mmol})$, and anhydrous EtOH $(32 \mathrm{~mL})$. The reaction mixture was stirred at ambient temperature until the formation of imine was complete as indicated by TLC and UPLCMS. After $3 \mathrm{~h}$ the reaction mixture was cooled to $0{ }^{\circ} \mathrm{C}$, then $\mathrm{NaBH}_{4}$ ( $93.5 \mathrm{mg}, 2.47 \mathrm{mmol}$ ) was added in small portions. The reaction mixture was stirred for $30 \mathrm{~min}$ at ambient temperature before being evaporated in vacuo. The resulting residue was dissolved in DCM $(25 \mathrm{~mL})$ then diluted with water $(25 \mathrm{~mL})$. The phases were separated, and the aqueous phase further extracted with DCM $(2 \times 25 \mathrm{~mL})$. The combined organic layers were dried over $\mathrm{MgSO}_{4}$, filtered, and evaporated in vacuo. The crude amine was purified by column chromatography (DCM, $\mathrm{MeOH}, \mathrm{NH}_{4}[98: 2+$ $0.25]$ ) giving the desired amine as a clear oil. The purified free base was transformed into the hydrochloride salt by dissolving it in $\mathrm{MeOH}(5 \mathrm{~mL})$ and passing $\mathrm{HCl}$ gas, generated by the addition of $35 \%$ aq. hydrochloric acid to $\mathrm{CaCl}_{2}$. The resulting suspension was cooled to $4{ }^{\circ} \mathrm{C}$ and left to crystalize over $24 \mathrm{~h}$. The solid formed was filtered, re-suspended in boiling 2-propanol, and diethyl ether was added dropwise until turbidity was observed. The flask was cooled to $4{ }^{\circ} \mathrm{C}$ overnight giving the crystalline product. The crystals were isolated by filtration and washed with cold diethyl ether before being dried under high vacuum to yield the desired amine hydrochloride $\mathbf{1}$ as a white solid (285 $\mathrm{mg}, 65 \%)$. Analytical data were consistent with previously published literature data.

Mp 220.5-222.0 ${ }^{\circ} \mathrm{C} ; \quad R_{f}=0.53$ (silica gel, 95:5:0.2, $\mathrm{DCM} / \mathrm{MeOH} / \mathrm{NH}_{3}$ ). ${ }^{1} \mathrm{H}$ NMR $(600 \mathrm{MHz}, \mathrm{MeOD}): \delta=7.30$ (ddd, $J=$ 15.0, 7.6, $1.8 \mathrm{~Hz}, 2 \mathrm{H}), 7.22(\mathrm{~s}, 1 \mathrm{H}), 7.09(\mathrm{~s}, 1 \mathrm{H}), 6.93-6.88(\mathrm{~m}, 2$ H), $4.25(\mathrm{~s}, 2 \mathrm{H}), 3.91(\mathrm{~s}, 3 \mathrm{H}), 3.83(\mathrm{~s}, 3 \mathrm{H}), 3.26(\mathrm{dd}, J=8.9,6.5$ $\mathrm{Hz}, 2 \mathrm{H}), 3.10$ (dd, $J=8.9,6.5 \mathrm{~Hz}, 2 \mathrm{H}) .{ }^{13} \mathrm{C}$ NMR $(151 \mathrm{MHz}$, MeOD): $\delta=157.48,157.37,152.73,133.67,132.59,132.42$, 121.06, 118.65, 117.12, 116.29, 115.95, 115.75, 101.24, 57.15, 56.71, 48.30, 47.45, 28.82. HRMS-ESI: $m / z$ calcd for $\mathrm{C}_{18} \mathrm{H}_{21} \mathrm{~N}_{2} \mathrm{O}_{3}$ $[\mathrm{M}+\mathrm{H}]^{+}:$313.1546; found: 313.1546; HPLC: $t_{\mathrm{R}}=17.51(96.5 \%)$. 